\title{
Collaborative Governance Optimization in Supervision Division of Manpower and Transmigration Office of the Special Region of Yogyakarta
}

\author{
Putri Adibatur Rohmah ${ }^{1,}$ Dwi Harsono² \\ Department of Public Administration Faculty Social Science Yogyakarta State University ${ }^{1,2}$ \\ putri.adibatr.15@gmail.com¹,dwiharsono@uny.ac.id ${ }^{2}$
}

\begin{abstract}
The purpose of this study was to describe the process of collaborative governance and find out the supporting and inhibiting factors in collaborative governance optimization in supervision division of manpower and transmigration office of The Special Region of Yogyakarta. The design of this research was descriptive qualitative. The results of the study showed that the optimization of collaborative governance in supervision division of manpower and transmigration office of The Special Region of Yogyakarta could not be said to be optimal in the process of optimizing internal collaboration. This can be seen from the principles of bureaucracy according to Sahya Anggara (2012: 395) which shows that internal collaboration is still blocked by miscoordination and lack of harmony between sections. Whereas for the optimization process of external collaboration carried out with BPJS Ketenagakerjaan (Social Security Card), Yayasan Annisa Swasti, PT Ajisaka Nusa Ilmu indicated that the optimization of collaborative governance in improving labor inspection has been carried out optimally by each stakeholder but the effort was slightly hampered because there were still many companies that were not compliant in implementing labor norms so that the level of labor compliance cannot be achieved optimally.
\end{abstract}

Keywords. Optimization, Collaborative Governance

\section{Introduction}

In facing 4.0 era of the Central Government has a deal with a strategy that later government agencies at the local level can play the role and function, the idea of the strategy launched by the central government is Reforms 4.0 wherein the draft there are three main aspects to be a reference one of which is a collaboration. Collaboration itself is a concept of government order that is explained in the theory of collaborative governance. Collaborative governance has broad meaning as one of the processes or structures of decision making and management of government cooperation with cross-sectoral, private, and community governments aimed at addressing a problem that cannot be solved [1]. Collaboration is an act of cooperation in government organizations, as well as a resolution of a problem to several actors involved or not directly involved in the administration of government programs. Then innovation, in this case, the government is required to be able to create an atmosphere of public service with new concepts and ideas. In meeting the innovation strategy, local government agencies are required to use the principles of accountability, credibility, and responsibility, especially in the management of operational activities and institutional supervision, especially in the implementation of labor inspection activities. 
The supervision division of manpower and transmigration office of The Special Region of Yogyakarta is one of the fields that functions to conduct supervision in promoting and ensuring that companies have implemented labor laws. The duties and functions have been recorded in the Governor of Yogyakarta Decree No. 62 of 2015 Article 23. For the flow of work operational activities. The fields are divided into two sections, namely the work norms section, and the OSH (Occupational Health and Safety) norm section. In the division of tasks and internal coordination functions between employees are divided into two parts of a total of 32 employees in the supervision division, there are about 9 people who occupy the secretariat section, while the remainder is placed in a special division of supervision by the area of expertise of each employee. This section was formed to carry out field visits directly to carry out the oversight function of companies in Yogyakarta.

At the time of the internship, the researcher found a pattern regarding the state of the employee even though the division of tasks and authority had been determined to each employee, internal coordination in this field was still not running optimally. Because there are still some employees who do not carry out their duties properly. Especially in matters of the secretariat, the implementation of duties and authority in managing the administration is mostly carried out by female employees, while male employees are often not seen so that in this point of view the first thing to do is to examine the internal collaboration process in the supervision division in conducting internal coordination between employees.

The coordination will be seen using organizational principles proposed by Sahya Anggara [2] consisting of:

1) The organization must have goals. This means that the goals in an organization will provide a stimulus to members to optimize performance through efforts (efforts, inspiration) under the unity of direction of movement and leadership.

2) There are a homogeneous assignment and division of labor. The goals set by the organization mandate that all human resources within the organization can work and coordinate. The division of tasks and division of labor must be accompanied by rights and authority over balanced power.

3) A balance between rights, power, and responsibility. The granting of rights to a person in an organization must be by following per under the responsibilities and powers it carries.

4) Unity of hierarchical command. This principle implies that the organization of each organization must follow the command of superior-subordinate relations, must not be stuck, and the flow of information and delegation of tasks must be carried out by the request of superiors.

5) Communication between leaders and subordinates must occur in harmony. To support the success of the organization, leaders and subordinates must have a sociological relationship of mutual need and mutual respect.

6) Coordination and appreciation. This principle states that the resources in the organization must be able to cooperate on the division of tasks that have been delegated because the tasks that have been fielded are bound to one another. While appreciation which meant that members of the organization should have the initiative to act in securing the state of the organization in the event of non-synchronous.

Then based on the Economic System of the development of SMEs in Yogyakarta stating that the number of companies in Yogyakarta has been developing every year, data analysis can be seen in the following graph: 
Table 1. Data shows that the development of companies

\begin{tabular}{lrrrr}
\hline Scale enterprises & $\mathbf{2 0 1 6}$ & $\mathbf{2 0 1 7}$ & $\mathbf{2 0 1 8}$ & \multicolumn{1}{c}{$\mathbf{2 0 1 9}$} \\
\hline Microbusiness & 130,525 & 135,799 & 141,991 & 143,385 \\
Small business & 59,655 & 62,042 & 64,896 & 65,533 \\
Medium business & 36,031 & 37,472 & 39,196 & 39,581 \\
Big business & 12,408 & 12,904 & 13,498 & 13,631 \\
\hline Total & 238,619 & 248,217 & 259,581 & 262,130 \\
\hline \multicolumn{5}{c}{ Source: Bapepda Yogyakarta }
\end{tabular}

Based on these data shows that the development of companies in Yogyakarta continues to experience growth every year so that the Supervision Division of Manpower has a great responsibility to supervise companies in Special Religion of Yogyakarta. For overseeing economic growth in Yogyakarta so that the welfare of workers is assured by granting the rights that must fulfil by companies.

Usman Hadi (2019) said that there are approximately 600 companies listed in Manpower and Transmigration Office of the Special Region of Yogyakarta will however still approximately 300 new companies registered employees in the social security program. On the other hand, the Supervision Division of Manpower and BPJS Ketenagakerjaan have tried to carry out employment socialization to the companies [3]. Whereas for the latest problem that just happened in 2019 on the official website of the Manpower and Transmigration Office of the Special Region of Yogyakarta: PPNS of the Supervision Division of Manpower (Civil Servant Investigator) has completed four companies in Bantul Regency and Sleman Regency with varied motives, for example not ratifies company regulations, does not participate in labor social security and OHS equipment that is not by the standards. The previous sanctions followed by Kite Award memorandum (I,II) but because the warning is ignored then the investigators take act decisively through legal channels in collaboration with the District Court for criminal sanctions for violations of the company.

Through this phenomenon the second objective of this study is to look at the process of external the collaboration was undertaken by the Supervision Division of Manpower which are intertwined with BPJS Employment, PT Ajisaka Nusa Ilmu, Foundation Annisa Swasti, and One of the Profit Companies (Hotel X) by using collaborative governance theory according to Ann Thomson and James Perry (2006) in Eko Priyo et al [4] suggests several developments in collaborative governance frameworks, including:

1. Negotiations in this situation the government as an initiator of cooperation to invite the private sector and civil society to discuss looking for alternatives for a particular problem. Meanwhile, in the process, the stakeholders bargained.

2. Commitment is a basic series of cooperation between stakeholder actors to engage with each other in achieving agreed goals.

3. Implementation under the auspices of the assessment, in the implementation process, is a form of evaluation of the commitments agreed upon. Also, the assessment was placed to maintain cooperation and see each process among stakeholders in the collaboration role.

This research is relevant to research conducted by Tika Mutiarawati and Sudarmo (2017)[6]titled Collaborative Governance in Handling Rob in Bandengan Urban Village, Pekalongan City. This study aims to determine the role of the government in implementing collaborative governance to solve the tidal flooding problem in Bandengan Village and to find information about supporting factors and obstacles. The equation in this research is about the collaborative governance process. 
This research is important because the results of this study are expected to provide a reference for the implementation of collaborative governance in the Supervision Division and stakeholders involved to further enhance its role in optimizing collaborative governance in the Field of Manpower and Transmigration in Yogyakarta.

\section{Methods}

This type of research is a descriptive study with a qualitative approach. This research was conducted in the Supervision of Manpower Supervision of Manpower and Transmigration in Yogyakarta, Annisa Swasti Foundation, BPJS Employment, PT Ajisaka Nusa Ilmu, and Hotel $X$. This research was conducted from 3 December - 28 December 2019. The research subjects consisted of Head of Labor and OHS Oversight Section, Head of Work Norms Section, Head of Occupational Safety and Health Section, Employees, and The employees of Supervision field, Head of BPJS Ketenagakerjaan, Admin Hotel X, Director of Yasanti, and Director of PT Ajisaka Nusa Ilmu. While for data collection techniques, among them:

\section{a. Observation}

In this study, researchers used non-participant observation. The researcher made observations related to the optimization of collaborative governance in the Supervision Division of Manpower.

\section{b. Interview}

In this study, researchers used structured and unstructured interview techniques. Structural interviews were conducted using a list of questions that had been prepared. While unstructured interviews are interviews conducted using utilizing employing through the questions given following the flow of information provided by the resource persons.

\section{c. Documentation}

Documents used in this the study was obtained from secondary data consisting of letters news, archived p, journals, guidelines, regulations, laws such as Law of the Republic of Indonesia Year 2014 Number 23, of the Local Government, Regulation Yogyakarta Governor 2015 Number 62 Article 23, concerning the Duties and Functions of the Disnakertrans DIY, Regulation of the Minister of Manpower No. 33 of 2016 concerning Procedures for Labor Inspection, the Governor of Yogyakarta Decree No. 62 of 2015 concerning List of Duties and Functions of Manpower and Transmigration of Yogyakarta, and Government Agency Performance Reports 2018.

\section{Results And Discussion}

Constitution Number 23 of 2014 concerning Regional Governments of the Supervision Division, which was originally the authority at the Regency / City level has now been transferred to the province by the Ministry of Manpower and Transmigration of the Republic of Indonesia to support the Making Indonesia 4.0 strategy. Through this policy, the Supervision function now can be optimized for its movement and authority.

Previously the implementation of the labor inspection function was constrained because many companies had branches outside the Regency / City and often received intervention from the Regency / City government. Now the motion has been expanded and the accountability report has been tightened directly to the Indonesian Ministry of Manpower. 
Through this, the Manpower and Transmigration Department of Manpower and Transmigration in Yogyakarta must carry out innovation to uphold the principles of good governance by improving public services. To improve as a government agency is currently working on optimizing its tasks and functions so that in this study there are two aspects of the results and what will be presented.

a. Optimization of Internal Collaboration Using the Principles of Sahya Anggara Organization (2012) as follows:

1) The organization must have a purpose

The Supervision Division are formed to promote and ensure labor compliance. This has been stated in the vision and mission of the Department of Manpower and Transmigration. While the main purpose held by the Supervision Division is compliance company employment in implementing labor norms and OHS norms. This is done solely to ensure the welfare that must be given by the employer and obtained by the work recipient.

2) There are homogeneous assignments and division of labor

From the overall implementation of the Supervision Division, three basic references form the basis of preventive educative, non-juristic responsive, and judicial reprehensive. Inspections entered into the educational preventive phase are carried out by labor inspectors when carrying out company visits or through routine surveillance activities. Meanwhile, non-judicial respiration actions are dedicated in the form of warning notes to companies that do not meet the supervisor's request when conducting visits. The memorandum was issued in stages, namely memorandum I and II. For the Judicial Respective stage is the final action carried out by PPNS, where the action is carried out after the memorandum II is not fulfilled by the company. In this stage, PPNS will work together with legal institutions to bring green shirt cases.

3) The balance between rights, power, and responsibility

The provision of duties to employees refers to applicable laws. In the implementation of the job description, the scope of employees is divided into two parts, namely the work norms section, and the OSH norm section. Each section carries out its duties and functions by the authority delegated. Meanwhile, supervisors / functional employees carrying out labor inspection tasks are given according to specifications/expertise they have.

4) Unity of hierarchical command

Delegation of authority and duties in the Supervision Division under the organizational structure. The Head of Supervision Division occupies the highest position in the internal arrangements of the Supervisor, while there are two Section Heads who assist the coordination process between employees. But in the implementation of labor inspection supervisors / functional employees can face directly to the Head of Division to conduct discussions related to problems found in the field. However, in general, these discussions were often conducted through the Head of Section concerned in advance. The unity of the command line changes depending on the degree of urgency of the problem.

5) Communication between leaders and subordinates must occur in harmony.

Communication between Head of Division and Employees seemed goes in one direction, where interaction to create harmonious relations was only carried out by The Head Division while some employees were less sympathetic to the initiative so employee cohesiveness could be said to be lacking. Many employees who are easy- 
going against The Head Division e.g rare phenomenon in the room of employee supervisors would, however, be found in the canteen.

6) Coordination and appreciation.

Coordination is happening among employees are goodwill but less than the maximum, some employees do not run main tasks and functions then become overlap. Whereas the appreciation of employees in the Supervision Sector are still considered to be less than maximal because it collides with ego and personal conflicts between employees. For example, The Head Division giving task to handle WLKP (Obliged to report about employment) for customers to two employees, but it was ignored because they both have personal conflict.

b. Optimization of External Collaboration Using the Collaborative Governance Model from Anne Thomson and JL Perry (2006) as follows:

1) Negotiation

The Supervision Division as a representative of the provincial government has the initiative to resolve the problems encountered in carrying out labor inspection in the Province of Yogyakarta in collaboration with outside parties by the mandate of the policy. In the process of negotiation, the initial step undertaken by this field is to conduct a personal dialogue (door to door) regarding the problems faced by the organization in labor affairs and find alternatives that can be carried out together with stakeholders. For example, communication between the BPJS Employment and Labor Inspector in increasing the level of compliance of the company to follow the company's membership.

2) Commitment

Alternatives that have gone through a process of dialogue in negotiations are then included in the form of cooperation in the same goal. The form of commitment held by each stakeholder is contained in its vision and mission. Whereas the foundation of commitment between the Supervision Sector and several stakeholders is contained in the form of a written cooperation agreement, for example in the form of an MoU, a letter of cooperation, and others. For example, the MoU between the supervision division to created WASPADU forum.

3) Implementation

The manifestation of cooperation established between The Supervision Division with the holders formed in a circle of interactions that affect one another. Aside from being an initiator The Supervisor also has a function as a guarantor for the continued implementation of labor inspection. For example, the continuation of cooperation between the Labor Inspection Division and Yasanti, the two of them often hold meetings to discuss the issue of women's employment and together look for solutions in finding alternatives to existing problems.

c. Inhibiting and Supporting Factors for Collaborative Governance Optimization in Supervision Division of Manpower and Transmigration Office of the Special Region of Yogyakarta

1) Inhibitory factors

a) Social factors: the implementation of collaboration cannot run optimally if the internal collaboration that occurs between employees is still insulated by miss-coordination and coordination among the low levels. Whereas for external collaboration lies in the company's level of compliance which is still low in implementing labor norms in the company. 
b) Technology factors: the advancement of science and technology may have a positive impact on the lives of human beings. But not for the Field of Supervision Division, it makes harder for the secretariat staff to make adjustments in the management of the public service system. For example, the Compulsory Employment Report (WLKP) service system that was previously given manually but right now replaced by reporting in the form of a website and the website is still in maintenance so that technical problem always happened.

2) Supporting factors

a) Geographical factors: in the implementation of Supervision Division administrative conditions of Yogyakarta provides benefits for supervisors in reaching companies that are scattered in the Regency / City. Through this, Employees can save time and money.

b) Resource factor: the implementation of oversight of the budget, spellings originate from the Yogyakarta Regional Budget which is given annually by the local government. Whereas human resources in the Field of Supervision is the mobilization of the City / District Manpower Office after the decision to move Supervision to the provincial level. At present, the Supervision Division has all of the specialists for the implementation of OHS inspection, only lacking construction specialists that do not yet exist and several legal specialists for the implementation of work norm inspection.

c) Policy factors: since oversight has been transferred to the provincial level, the scope of Supervision Division over the region and the wider authority has been made to make it easier for employees to inspect and a crackdown on companies. In addition to simplifying the supervision process, this field collaborates with cross-sectoral institutions such as BPJS to ensure that the company has provided social security to the workers, and if there is any non-compliance in a company with an easy process the supervisor will establish cooperation with the Regional Police to conduct an investigation then brought to the court. Besides, to facilitate coordination between Supervision Division and the Provincial Government, regular meetings are often held between the City / District and Provincial which are chaired directly by the Regional Secretariat of Yogyakarta.

\section{Conclusions}

Based on the results of research on Collaborative Governance Optimization in the Supervision Division of Manpower in Yogyakarta states that the process of optimizing internal collaboration using organizational principles from Sahya Anggara (2006) and external collaboration using collaborative governance models from Ann Thomson and JL Perry (2006) The Supervision are under indicators that have been determined but cannot be said to be optimal. Internal collaboration that exists between employees is still limited by miscoordination and harmony between the lower parts. While the granting of authority and duties is by the nature of an organization. Daily work is carried out according to the established command chain.

As for the process of optimizing external collaboration using the Collaborative Governance model from Ann Thomson and JL Perry (2006) conducted by the Supervision Division, BPJS Ketenagakerjaan Yogyakarta, PT. Ajisaka Nusa Ilmu, Annisa Swasti Foundation, and Hotel X can be said optimal but it's not enough, it is based on companies compliance in implementing labor norms that are still low. 
Based on the results of research on Optimizing Collaborative Governance in the Field of the Supervision Division of Manpower in Yogyakarta, there are still some problems that must be corrected; therefore, researchers provide the following suggestions:

1. To improve internal collaboration between employees, The Head Division must have the courage to be strict in imposing sanctions on staff who do not carry out their duties optimally.

2. The relationship between head division and employees who seem to be one-way must be improved immediately by seeking informal and formal meetings. But it is more advisable at informal meetings such as holding a joint picnic between employees.

3. The government needs to open/recruit new employees who are placed in supervision, given the number of supervisors and companies in Yogyakarta are not comparable.

4. The need to increase visits, outreach, counselling, and coaching to companies and the community together with stakeholders.

\section{References}

[1] Kirk, et al. An Integrative Framework for Collaborative Governance. Published by Oxford University Press on behalf of the Journal of Public Administration Research. doi:10.1093/jopart/mur011 (2011:3)

[2] Anggara, S. Ilmu Administrasi Negara (kajian konsep, teori, dan fakta menciptakan Good Governance). Bandung: Pustaka Setia (2012:12)

[3] Hadi, Usman. Banyak Pekerja Bantul belum Dapatkan BPJS Ketenagakerjaan. Artikel diambil pada diakses pada tanggal 29 November 2019 Pukul 19:58, dari https://jogja.tribunnews.com/2016/11/12/banyak-pekerja-di-bantul-belum-dapatkan-bpjsketenagakerjaan. (2019)

[4] Priyo, Eko Purnomo, dkk. Collaborative Governance dalam Tata Kelola Hutan Berbasis Masyarakat. Yogyakarta: LP3M (2018: 15). 